\title{
Hollywood in the Heartland: A Review Essay
}

\author{
BARBARA CHING
}

The Book of Iowa Films, by Marty S. Knepper and John Shelton Lawrence. Berkeley, California, and Sioux City, Iowa: The Book of Iowa Films Press, 2014. x, 272 pp. Illustrations, bibliographic references, appendixes, index of Iowa films. $\$ 25.95$ paperback.

Hollywood in the Heartland, exhibit curated by Leo Landis. Des Moines: State Historical Museum of Iowa, June 27, 2014-December 2016.

WE NOT ONLY GROW POPCORN in Iowa; the state has also proven to be fertile ground for the film industry. In The Book of Iowa Films, Marty Knepper and John Lawrence note that "research in well-indexed filmographies revealed that no comparably scaled body of films exists for our neighbors in Kansas, Minnesota, Nebraska, Missouri, or South Dakota" (5). They hypothesize that Iowa earned its cinematic role as "the representative heartland state" (11) because it nurtured literary talent and welcomed filmmakers in search of settings for stories involving ruralurban conflicts, historical events, and nostalgic situations (5). In the process of cataloguing 410 films, they viewed as many as they could locate and conducted research in trade newspapers and published reviews to learn about the others. After extensive searches, they concluded that many of the oldest films simply no longer exist, although they speculate that some of the unseen films may eventually turn up under different titles. On the book's website and blog, they update readers on films they have learned

THE ANNALS OF IOWA 74 (Spring 2015). (C) The State Historical Society of Iowa, 2015. 
about since publication and note that they self-published the current book because they knew a second edition would be necessary (www.bookofiowafilms.com).

Self-publishing also allowed for a more idiosyncratic chapter structure than the typical academic book. The book has an introduction followed by five chapters and four appendixes. Chapter one lists all of the films chronologically and places each one into one of six categories: (1) fictional films set in Iowa; (2) historical films set in Iowa; (3) films about traveling Iowans; (4) Iowa documentaries (many of which are short films made for Iowa Public Television); (5) films made in Iowa although supposedly set elsewhere or nowhere in particular; and (6) films that mention Iowa. Chapter two takes up more than half the book; it repeats, rearranges, and expands chapter one's lists by grouping the films by category and summarizing all but the "Iowa mention" films. The index creates an alphabetical listing; there is no index of names or other items.

The listed films range from 1918, when The Strange Woman, the first film with an Iowa setting, was released, to 2013. The authors go on to divide the films by drawing a line between twentieth-century themes and new directions in the twenty-first century. The twentieth-century themes are "building the nation through agrarian virtue," "defending the nation," "magic pastoralism," "puncturing Iowa pastoralism and moralism," "Iowans who travel," "Iowa as a place to work," and "agrarian realist visions of Iowa." In the twenty-first century, new, more "realistic" (that is, less pastoral) themes and genres prevail, including social issues such as racism and food safety and forays into genres like horror and science fiction - although films touching on Star Trek's Captain Kirk, to be born in Riverside, Iowa, in 2228, have appeared since 1986 (Star Trek IV).

The categories used to structure the filmography vary in their usefulness and specificity. Although agriculture may play a more definitive role in Iowa than elsewhere, all states are places to work, and some residents of all states travel. The "Iowa mention" category currently lists 51 films, but since the authors hope to "be as comprehensive as possible" (223), diligent pursuit of this angle is likely to result in hundreds of further entries. As colleagues at Morningside College in Sioux City, Iowa, Knepper 
and Lawrence have been researching and teaching about Iowa films since 1996, so they no doubt have posed and answered bigger questions than how to categorize films. Why study Iowa films at all? What understanding of the state and their lives did their students gain? Which films were most popular and which most polarizing? What nerves did they strike? I would like to learn more about why and how this body of film mattered to the original audiences and to the audience that Knepper and Lawrence hope to reach now.

More detailed discussions would also add meaning to the catalog. In Appendix C, the authors reprint an excellent essay they published in 2006, "World War II and Iowa: Hollywood's Pastoral Myth for the Nation," which demonstrates their ability to contextualize a handful of Iowa films in a way that shows their importance and their specific use of rural settings, especially the way rural settings are presumed to build strong, patriotic, selfsacrificing characters. Focusing on five films made from 1941 through 1946, the authors argue that presenting Iowans as model citizens built support for America's entry into World War II. They then point to Billy Wilder's A Foreign Affair (1948) to show the rapid postwar emergence of more jaundiced views of Iowans and their patriotism. Although an extensive treatment of all 410 films would exceed the scope of any book, more analytical summaries would have been helpful and feasible. For example, in their summary of Gus Van Sant's Promised Land (2012), the authors refer to a review by Richard Corliss arguing that the film is a retelling of The Music Man with fracking rights taking the place of musical instruments. A more consistent eye for this kind of connectivity and subtle remaking would animate and strengthen the assertion that Iowa films have a tradition and that the twentyfirst century brought new approaches and new themes.

AS KNEPPER AND LAWRENCE were finishing their book, an exhibit titled Hollywood in the Heartland opened at the State Historical Museum of Iowa in Des Moines. (Knepper served as a consulting scholar.) The authors consider this exhibit "a visual complement" to The Book of Iowa Films (x). The exhibit's scope, though, is in some ways more ambitious. Like a multiplex in a mall, Hollywood in the Heartland shows something for everyone. 
The exhibit contextualizes the films set in Iowa with a history of the technology, business, and culture of film viewing as well as display cases dedicated to actors from Iowa, starting with twentiethcentury stars such as Indianola's Lane Sisters, Lillian Russell, Donna Reed, and John Wayne, and enticing younger visitors with twenty-first-century sensations such as Michelle Monaghan and Ashton Kutcher.

Beginning with the kinetoscope, a machine designed to play a short film for one viewer, the exhibit charts the development of the shared experience offered by movie theaters in Iowa's larger cities and small towns. These theaters, like the movie studios that supplied them with films, were created as businesses. Opera houses in Dubuque and Davenport, for example, became "movie palaces" when it was clear that lots of tickets would be sold; purpose-built cinemas came later, and many small towns had one. The exhibit features old-fashioned movie theater seats to relax in and view the film clips on display, evoking dark, velvety nights out in front of the big screen. Vintage film projectors, ticket machines, and popcorn poppers reinforce the historicity. Similarly, clips play on the windshield of a big-finned car to mimic summer nights at the drive-in. Robert Fridley, founder and president of the Fridley Theatre Corporation, the largest Iowa-owned theater chain, gets his turn on the screen, talking animatedly about his 60 years of experience in the industry. Our shrunken, solitary twenty-first-century screens may change our shared understandings of film-mediated Iowa, although neither the book nor the exhibit attempt to speculate on the future of movie-going.

Hollywood in the Heartland implicitly makes an argument that The Book of Iowa Films, with its equalizing emphasis on cataloguing, does not make: judging from the space devoted to them, the most significant films about Iowa are Field of Dreams (1989), The Bridges of Madison County (1995), The Music Man (1962), and two versions of State Fair, the 1933 original and the 1945 musical version with songs by Rodgers and Hammerstein. In the authoritative talking head style of a documentary, Knepper provides lucid and insightful commentary on each of those films.

All of them convey the theme of "Iowa as a Magical Place." Field of Dreams, with its flattering Q\&A dialogue-"Is this heaven?" "No, it's Iowa" - exemplifies this theme most strongly, 
but River City works its magic on Harold Hill, helping the "music man" become what he first pretended to be: a man concerned with the greater good of the community. Whenever the "76 Trombones" clip cycles through The Music Man display, this victory march for "Iowa nice" drowns out all other audio in the exhibit. In The Bridges of Madison County, farm wife Francesca, an Italian sophisticate turned war bride, and the globe-trotting photographer Robert Kincaid kindle and renounce their love in support of the principles of Madison County - the family and the farm - but not before experiencing a few transformative days of rural romance. The State Fair films' focus on the Frake family, with a son and daughter at the point of choosing their future, allows for more perspectives. (Father Frake's exuberant pride in the hog he intends to show at the Iowa State Fair also permits a little snickering at stereotypical rubes.) After meeting potential mates at the state fair, the son chooses to stay down on the farm rather than follow the Chicago chanteuse who charms him on the midway while the daughter goes to Chicago to marry the journalist she met. The musical version turns Iowa into a portable feast. "All I Owe Ioway" celebrates the nourishing food that makes us who we are - not only physically healthy but also morally sound, upright members of society whether we stay in Iowa or carry a bit of it with us.

The exhibit also devotes significant attention to Cold Turkey (1971). Like The Wonderful Thing (1921), the first film made in Iowa, Cold Turkey generated lots of excitement because of the contact with Hollywood stars: Norma Talmadge in Centerville in 1921, and Dick Van Dyke in Greenfield in 1971. Although Cold Turkey, a film satirizing heartland morality in "Eagle Rock, Iowa," enjoyed little critical or box office success, Greenfield enjoyed the experience so much that the town invited the cast and crew back for a 30-year reunion that generated another movie-an Iowa Public Television documentary about it in 2000.

FIELD OF DREAMS and The Bridges of Madison County were made nearly 20 years ago; no subsequent Iowa-related film has matched their box office success. The means-of-production narrative that parallels the film history suggests that these two may have been the last Iowa blockbusters. Media is no longer mass, 
this story goes. Digital cameras have made filmmaking far less expensive, so myriad independent films, available for streaming or showing at the film festival nearest you, now explore what it means to be made in Iowa or how Iowa and Iowans are no different from anybody else. The Book of Iowa Films quantifies this development clearly: "the pace of Iowa film production has increased dramatically. From 1918 through 2000, our filmography lists 251 Iowa films; in the twelve years from 2001 through 2013, 159 films appeared" (17). Without advertising campaigns or trailers to preview the coming attractions and entice a large audience, these films reach the buffs who seek them out. At the same time, it could be argued that these films are the most intensely Iowan of all those described in The Book of Iowa Films. They are written by Iowa screenwriters (rather than adapted from previously published novels, plays, or short stories) and performed, directed, and produced by Iowans in every corner of the state. 